\title{
Spin Chemistry: Coherent Spin Dynamics Rules Chemical Reactions
}

\author{
Jörg Matysik
}

Published online: 14 December 2011

(C) The Author(s) 2011. This article is published with open access at Springerlink.com

It is a great honor to edit a special issue of Applied Magnetic Resonance, in particular if the area presented is not magnetic resonance spectroscopy itself. The topic of this special issue, spin chemistry [1], can be considered as upspring of magnetic resonance spectroscopy. On the other hand, the field of spin chemistry contributed significantly to the methodological improvement of both NMR and EPR. Indeed, spin chemistry was born with the discovery of the CIDEP (chemically induced dynamic electron polarization) effect by EPR spectroscopy in 1963 [2], followed soon by the observation of CIDNP (chemically induced dynamic nuclear polarization) in chemical dark [3-6] and light [7] reactions. The explanation of these phenomena was presented as so-called 'radical pair mechanism' (RPM) in 1969 $[8,9]$. That revolutionary reaction scheme allowed for the first time nuclear spin states to decide on the fate of a chemical reaction. Since reaction enthalpies are dramatically larger than spin energies, such kinetic control mechanism was a big surprise, in particular for chemists. Soon magnetic field effects (MFEs) were observed on chemical reaction systems $[10,11]$ and discussed in particular on photosynthetic systems [12-14] which led to the theory of spin-correlated radical pairs [15, 16]. Upon discovery of the solid-state photo-CIDNP effect [17], the concept of spin-correlated radical pairs was extended to solid-state conditions by introduction of coherent anisotropic interactions [18-23] and to natural low-field conditions by allowing for S-T mixing [24]. Such coherent spin dynamics at natural conditions might explain the persistence of the solid-state photo-CIDNP effect in natural photosynthesis [25]. Another hot field in which spin-chemical research aims for understanding of natural phenomena is dedicated to light-dependent magnetosensing by animals via a RPM [26-28].

In this special issue of Applied Magnetic Resonance, a range of spin-chemical effects on chemical and biological electron transfer systems and complementary

\footnotetext{
J. Matysik ( $₫)$

Leiden University, Leiden Institute of Chemistry, Einsteinweg 55, 2300 RA Leiden, The Netherlands e-mail: j.matysik@chem.leidenuniv.nl
} 
experimental methods, i.e. EPR and NMR, is reported. First, spin-chemical effects in chemical systems are presented: Basu and coworkers [29] observe an MFE on photoinduced electron transfer reactions between three aromatic amines and acridone in ethanol at low fields. Joonwichien et al. [30] describe MFEs on the photodegeneration of methylene blue dye. Bagryanskaya et al. [31] study spinselective excited state relaxation and reactivity of deoxybenzoin (DOB) and benzophenon (BP) molecules by time-resolved EPR spectroscopy. Van der Est and coworkers [32] discuss the time-resolved EPR signature of spin-selective electron transfer in series of metalloporphyrin pyridyl-linked naphthalene diimides.

Second, spin-chemical effects on biological systems are described: Alia and coworkers [33] present photo-CIDNP data on photosystem I of plants. Hirayama et al. [34] discuss whether MFEs affect the light-dependent circadian clock in zebrafish. Third, an improved technique in solid-state NMR, a main tool in spin chemistry, is presented. Song et al. [35] show a new technique allowing for improvement of proton resolution in proteins. Hence, the present issue demonstrates that nowadays spin chemistry is a matured and lively field with increasing impact on both, magnetic resonance spectroscopy as well as general chemistry.

I express my gratitude to the authors who have contributed to this special issue. I am also grateful to Prof. K. Salikhov and Dr. L. Mosina. Without their efforts, the publication of this special issue would not have been possible.

Open Access This article is distributed under the terms of the Creative Commons Attribution Noncommercial License which permits any noncommercial use, distribution, and reproduction in any medium, provided the original author(s) and source are credited.

\section{References}

1. H. Hayashi, Introduction to dynamic spin chemistry, World Scientific, Singapore (2004)

2. R.W. Fessenden, R.H. Schuler, J. Chem. Phys. 39, 2147 (1963)

3. J. Bargon, H. Fischer, U. Johnson, Z. Naturforsch. A 22, 1551 (1967)

4. J. Bargon, H. Fischer, Z. Naturforsch. A 22, 1556 (1967)

5. H.R. Ward, R.G. Lawler, J. Am. Chem. Soc. 89, 5518 (1967)

6. J. Bargon J, Helv. Chim. Acta 89, 2082 (2006) (For personal account)

7. M. Cocivera, J. Am. Chem. Soc. 90, 3261 (1968)

8. G.L. Closs, L.E. Closs, J. Am. Chem. Soc. 91, 4549 (1969)

9. R. Kaptein, J.L. Oosterhoff, Chem. Phys. Lett. 4, 195 (1969)

10. R.G. Lawler, G.T. Evans, Ind. Chim. Belg. 36, 1087 (1971)

11. U.E. Steiner, T. Ulrich, Chem. Rev. 89, 51 (1989)

12. R.E. Blankenship, G.T. Babcock, J.L. Warden, K. Sauer, FEBS Lett. 51, 287 (1975)

13. A.J. Hoff, P. Gast, J.C. Romijn, FEBS Lett. 73, 185 (1977)

14. A.J. Hoff Q. Rev. Biophys. 17, 153 (1984) (for review)

15. P.J. Hore, D.A. Hunter, C.D. McKie, A.J. Hoff, Chem. Phys. Lett. 137, 495 (1987)

16. G.L. Closs, M.D.E. Forbes, J.R. Norris, J. Phys. Chem. 91, 3592 (1987)

17. M.G. Zysmilich, A. McDermott, J. Am. Chem. Soc. 116, 8362 (1994)

18. T. Polenova, A.E. McDermott, J. Phys. Chem. B 103, 535 (1999)

19. G. Jeschke, J. Chem. Phys. 106, 10072 (1997)

20. G. Jeschke, J. Am. Chem. Soc. 120, 4425 (1998)

21. G. Jeschke, J. Matysik, Chem. Phys. 294, 239 (2003)

22. E. Daviso, A. Alia, S. Prakash, A. Diller, P. Gast, J. Lugtenburg, J. Matysik, G. Jeschke, J. Phys. Chem. C 113, 10269 (2009) 
23. E. Daviso, G. Janssen, A. Alia, G. Jeschke, J. Matysik, M. Tessari, J. Am. Chem. Soc. 133, 16754 (2011)

24. G. Jeschke, B. Anger, B. Bode, J. Matysik, J. Phys. Chem. A 115, 9919 (2011)

25. J. Matysik, A. Diller, E. Roy, A. Alia, Photosynth. Res. 102, 427 (2009)

26. K. Schulten, C.E. Swenberg, A. Weller, Z. Phys. Chem. Neue Folge 111, 1 (1978)

27. T. Ritz, S. Adem, K. Schulten, Biophys. J. 78, 707 (2000)

28. C.T. Rodgers, P.J. Hore, Proc. Natl. Acad. Sci. USA 106, 353 (2009)

29. B. Chakraborty, S. Basu, Appl. Magn. Reson. (2011) doi:10.1007/s00723-011-0254-0

30. S. Joonwichien, E. Yamasue, H. Okumura, K.N. Ishihara, Appl. Magn. Reson. (2011). doi: 10.1007/s00723-011-0270-0

31. O. Krumkacheva, M. Tanabe, S. Yamauchi, M. Fedin, S.R.A. Marque, E. Bagryanskaya, Appl. Magn. Reson. (2011). doi:10.1007/s00723-011-0289-2

32. A.G. Moiseev, P.K. Poddutoori, A. van der Est, Appl. Magn. Reson. (2011). doi:10.1007/ s00723-011-0262-0

33. G.J. Janssen, E. Roy, J. Matysik, A. Alia, Appl. Magn. Reson. (2011). doi:10.1007/ s00723-011-0283-8

34. Y. Uchida, T. Shimomura, J. Hirayama, H. Nishina, Appl. Magn. Reson. (2011). doi:10.1007/ s00723-011-0275-8

35. C. Song, C. Lang, J. Mailliet, J. Hughes, W. Gärtner, J. Matysik, Appl. Magn. Reson. (2011). doi: 10.1007/s00723-011-0196-6 